\title{
MANUFACTURE AND EVALUATION OF A SIMPLE PROTOTYPE OF PEANUT SHELLER
}

\begin{abstract}
M. A. A., Mady*
ABSTRACT

A power-operated peanut sheller was manufactured and the performance was evaluated under different operational conditions. The experiments were conducted at drum rotary speeds of 150, 200, 250 and $300 \mathrm{rpm}$ (2.0, 2.67, 3.33 and $4 \mathrm{~m} / \mathrm{s}$.), feeding rates of 170,210 and $250 \mathrm{~kg} / \mathrm{h}$ and air speeds of 4.9, 6.8 and $8.8 \mathrm{~m} / \mathrm{s}$. The performance was evaluated in terms of output seed damage, shelling losses, undamaged seeds, un-shelling pods, shelling efficiency and machine productivity as well as cleaning ratio. The lowest seeds damaged and shelling losses of 2.45 and $1.32 \%$ while the highest undamaged seeds and shelling efficiency of 97.55 and $96.23 \%$ were obtained at drum speed of $150 \mathrm{rpm}(2.0 \mathrm{~m} / \mathrm{s})$ and feeding rate of 170 $\mathrm{kg} / \mathrm{h}$. The highest machine productivity of $250 \mathrm{~kg} / \mathrm{h}$ was obtained at drum speed of $300 \mathrm{rpm}(4 \mathrm{~m} / \mathrm{s}$.) and feeding rate of $250 \mathrm{~kg} / \mathrm{h}$. The highest cleaning ratio $98 \%$ was obtained at drum rotary speed of $150 \mathrm{rpm}$ and air speed of $8.8 \mathrm{~m} / \mathrm{s}$. But the lowest cleaning ratio of $94.8 \%$ was obtained at drum rotary speed of $300 \mathrm{rpm}$ and air speed of $4.9 \mathrm{~m} / \mathrm{s}$.
\end{abstract}

\section{INTRODUCTION}

$\mathrm{G}$ roundnut is the six most important oilseed crop in the world. It contains $48-50 \%$ oil and $26-28 \%$ protein, and is a rich source of dietary fiber, minerals and vitamins. It grows best on soils that are well drained, loosely textured and well supplied with calcium, potassium and phosphorous. Over 100 countries worldwide grow groundnut. Developing countries constitute $97 \%$ of the global area, $94 \%$ of the global production, $68 \%$ of global area and $25 \%$ of the global production, respectively, (Ntare, et al., 2014). peanut is generally recognized as one of the most important oil crops in the world because peanut oil is considered one of the best for cooking because of its high smoke point

*Assoc. Prof.; Agric. Eng. Dept.; Fac. Of Agric. Suez Canal University, Ismailia, Egypt. 
(Zafar et al, 1997). In Egypt, peanut ranked second place in terms of relative importance of total oil crop production after cotton seed. The total cultivated area was about 149 thousand feddan and Ismailia is ranked the third Governorate with 14 thousand feddan which yielded 22 thousand ton (CAPMAS, 2014). Peanut seeds are important nutritional and economical crop used for human feeding and for different industrial aspects such as sweets, peanut butter, paint, insecticides, nitroglycerin etc. Peanut shells are used in the manufacture of plastic, wallboard, fuel and cellulose. Singh and Thongsawatwong (1983) developed manual and power operated peanut sheller. The modified manual peanut sheller operated by two men, has a capacity of $32 \mathrm{~kg}$ ( $\mathrm{seed} / \mathrm{h}$ ) with about $4.8 \%$ breakage and $96 \%$ shelling efficiency. For the power-operated peanut sheller, a feeding mechanism and a blower were designed. The modified sheller has a capacity of about $175 \mathrm{~kg}(\mathrm{seed} / \mathrm{h})$ at 145 stroke $/ \mathrm{min}$ shelling bar speed and $20 \mathrm{~mm}$ clearance. The machine has $97 \%$ shelling efficiency with $4.7 \%$ breakage, $0.2 \%$ blower loss, $98.3 \%$ cleaning efficiency and power consumption of $2.2 \mathrm{~kW}$.

Kittichai (1984) developed a power-operated groundnut (peanut) sheller. $\mathrm{He}$ found that, the best performance of the sheller was achieved at $20 \mathrm{~mm}$ clearance and shelling bar speed of $180 \mathrm{rpm}$, at these parameters the capacity, shelling efficiency and percentage of breakage were $210.5 \mathrm{~kg}$ kernels $/ \mathrm{h}, 98 \%$ and $5.3 \%$ respectively. The power consumption of the sheller was about 1.0 to $1.1 \mathrm{~kW}$. Tayel and Khairy (1988) found that, the shelling operation depends largely on the impact force and partially on friction force, so the impact surface must be made from rigid and rough materials. Duraisamy and Manian (1990) developed a hand and power operated castor bean sheller. The output and shelling efficiency of power and hand operated castor bean sheller were $163 \mathrm{~kg}$ and $52.65 \mathrm{~kg}, 97.29 \%$ and $98.72 \%$ with kernel breakage of $0.82 \%$ and $0.88 \%$ respectively. Gore et al., (1990) reported that splitting of peanut kernels was vary common when moisture content below 10\%, but at high level of moisture content, bruising and hull damage were observed. They also reported that, the maximum efficiency was obtained at $180 \mathrm{rpm}, 18 \mathrm{~mm}$ concave-drum clearance, and $400 \mathrm{~kg} / \mathrm{h}$ feed rate at $13 \%$ M.C. The power consumption with one motor was $0.75 \mathrm{~kW}$. The manual sheller should be replaced by 
power operated one when manual shelling is more than 6.25 tons. ElSayed (1992) designed and fabricated a conical sheller to be used for shelling the peanut. The results indicated that, the shelling efficiency increases according to increase of speed at different clearances. However, increasing the clearance under the same speed lead to the lowest efficiency. The least value of economical losses of shelling reached 0.08 for shelling with beater and 0.11 for shelling with friction. Abo El-Kheir and Shouker (1993) reported that, increasing drum speed increases the rate of normal acting force for beater drum. In other words, as shelling speed increased, breakage increased for the same clearance, feed rate and moisture content. Singh (1993) stated that, the concave clearance influenced the kernel damage, shelling capacity and shelling efficiency. Abdel-Rahim (1994) defined the threshers according to the force obtained as follows:

- Mechanical rubbing and striping.

- Impact or impulse strike by a moving bar.

- Non-impulsive gradual acceleration of the grain.

Awady and El-Sayed (1994) reported that, the terminal velocity was found to be 4.3, 6.5, 6.8 and $7.2 \mathrm{~m} / \mathrm{s}$ for shells, unshelled, split and intact seeds respectively. The separation air speed of $5.7 \mathrm{~m} / \mathrm{s}$ was recommended for good separation of peanut seeds. Although hand shelling of peanut is a very low process and requires much time and labors but it gives minimum loses and seed damage. Helmy (1999) reported that the degree of cleanliness the peanut seed resulted from the reciprocating sheller increased remarkably at any moisture content, as air velocity increased and vice versa was noticed of seed recovery. Whereas, the air velocity increase from 4.43 to $10.11 \mathrm{~m} / \mathrm{s}$, at moisture contents of $17.12 \%$ increased degree of cleanliness from 88.37 to $98.87 \%$. But, the air velocity increase from 4.43 to $10.11 \mathrm{~m} / \mathrm{s}$, at moisture contents of $17.12 \%$ decreased seed recovery from 99.89 to $99.47 \%$. In order to establish the optimum air velocity, it is seen that the maximum degree of cleanliness and seed recovery $(96.1 \%, 9967 \%$ respectively) were obtained at air velocity 8.37 $\mathrm{m} / \mathrm{s}$ for peanut moisture content of $17.12 \%$. Mady (2000) found that, increasing shelling wheel speed and decreasing concave clearance and pods moisture content, the shelling efficiency and sheller productivity 
increased. The heights shelling efficiency of $98.81 \%$ and sheller productivity of $190.8 \mathrm{~kg} / \mathrm{h}$ were obtained at shelling wheel speed of 220 $\mathrm{rpm}(5.76 \mathrm{~m} / \mathrm{s})$, clearance of $10 \mathrm{~mm}$ and pods moisture content of $10 \%$. The results also indicated that, decreasing the shelling wheel speed and increasing the clearance tends to reduce the percentage of breakage and total losses at all pods moisture contents. The lowest percentage of breakage and total losses of 3.62 and $7.1 \%$ were found at shelling wheel speed of $140 \mathrm{rpm}(3.66 \mathrm{~m} / \mathrm{s})$, clearance of $22 \mathrm{~mm}$ and pods moisture content of $13.8 \%$. The sheller power consumption increased with increasing the shelling wheel speed and decreasing the concave clearance. Ikechukwu, et al., (2014) focused on the design and fabrication of a groundnut shelling and separating machine electrically powered by a $1 \mathrm{hp}$ motor. The machine has the capacity of shelling 400kg of groundnut per hour with a shelling and separating efficiencies of $95.25 \%$ and $91.67 \%$ respectively. The machine was fabricated from locally sourced materials, which makes it cheap and easily affordable and also easy and cheaper to maintain. It is also of light weight and comprises of the hopper, crushing chamber, separation chamber and the blower unit. During the process of testing, it was observed that majority of the groundnut pods that came out unshelled or partially shelled were the ones with one seed per pod and those with two small seeds in their pods. The objectives of the present study are to manufacture a simple prototype of peanut sheller suitable for Egyptian farmer and evaluate its performance under different operational parameters.

\section{MATERIALS AND METHODS}

This study aimed essentially to construct and evaluate a simple prototype of peanut sheller. The new mechanical sheller was constructed at the Agric. Eng. Dept., Faculty of Agric., Suez Canal Univ. The experiments were carried out at the Experimental Farm of Faculty of Agriculture, Suez Canal University. Peanut variety of Giza 6 was used in this study. The average peanut pods and seeds physical properties were as shown in Table (1).

Table (1). Peanut pods and seeds physical properties.

\begin{tabular}{|c|c|c|}
\hline pod diameter, $\mathrm{mm}$ & Seed length, $\mathrm{mm}$ & Seed Width, $\mathrm{mm}$ \\
\hline 17.2 & 18.93 & 9.35 \\
\hline
\end{tabular}




\section{Peanut sheller:}

The sheller consists of a rubber drum with a rough surface having a cylindrical shape assembled on an axial shaft of $30 \mathrm{~mm}$ diameter and rested on two bearings which were fixed on the frame that have dimensions of $48 \times 40 \times 90 \mathrm{~cm}$. The sheller concave was made from iron sheet of $1 \mathrm{~mm}$ thickness pierced to hole of $14 \mathrm{~mm}$ diameter and fitted under the drum at space of $22 \mathrm{~mm}$. Two pulleys (40 and $160 \mathrm{~mm}$ diameters) were fixed on each of motor and drum shaft respectively. The electric motor of $2 \mathrm{hp}(1.5 \mathrm{~kW})$ was connected by Inverter device (AC650 series) to provide or reduce the rotary speed of the electric motor. Under the peanut inlet opening, blower was fixed to clean the kernels from dust as shown in fig. (1).

\section{Experimental conditions.}

Shelling operation was studied as follows:

1- Four drum speeds of 150, 200, 250 and $3.0 \mathrm{rpm}(2.0,2.67,3.33$ and $4 \mathrm{~m} / \mathrm{s}$ )

2- Three levels of feeding rate of $(170,210$ and $250 \mathrm{~kg} / \mathrm{h}$ ).

3 - Three levels of air velocity of $4.9,6.8$ and $8.8 \mathrm{~m} / \mathrm{s}$.

\section{Measurements of the threshing process.}

The peanut sheller performance was studied through: -

1- Damaged seeds, $\%$.

3- Un-damaged seeds, $\%$.

5- Shelling efficiency, $\%$.

7- Cleaning ratio, $\%$.
2- Shelling losses, $\%$.

4-Un-shelling pods, $\%$.

6- Machine productivity, $\mathrm{Kg} / \mathrm{h}$.

\section{Damaged and undamaged seeds percentage}

Three samples of peanut were taken after shelling operation. Each sample was weighed and was divided into two portions, damaged seeds and undamaged seeds. The percentage of each portion was calculated as follows:

$$
\begin{gathered}
D_{s}=\left(M_{1} / M\right) \times 100 \\
U D s=\left(M_{2} / M\right) \times 100
\end{gathered}
$$

Where:

$D s=$ damaged seeds, $\%$,

$U D s=$ undamaged seeds, $\%$,

$M 1$ = mass of damaged seeds, $\mathrm{kg}$,

$M 2$ = mass of undamaged seeds, $\mathrm{kg}$,

$M=$ total mass of separating seeds, $\mathrm{kg}$. 


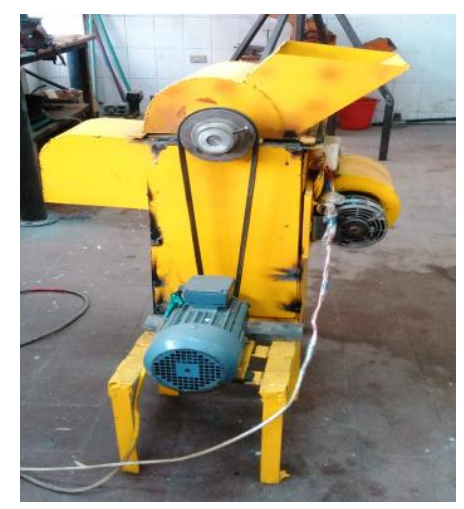

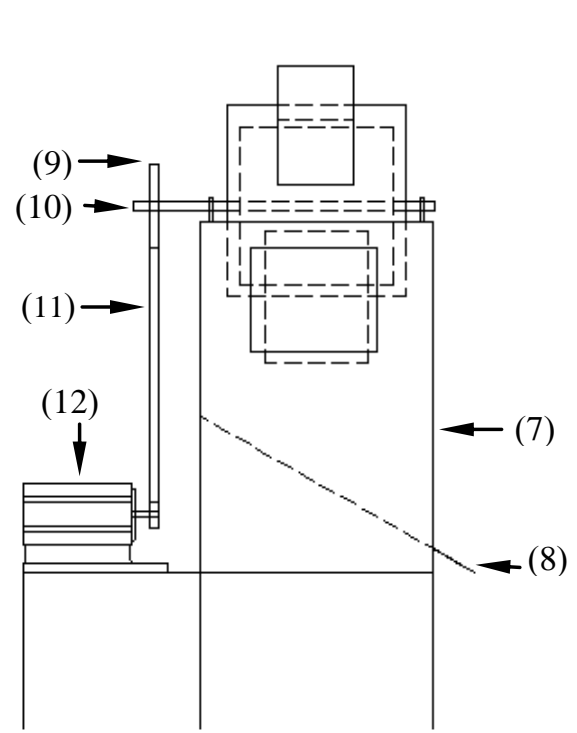

ELEV.

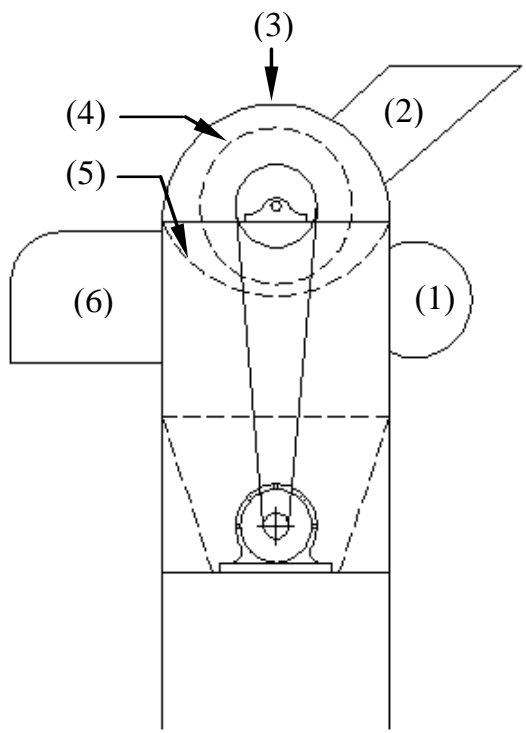

SID. V.
1 - Blower

4 - Drum

7 - Frame of machine

10- Drum shaft
2 - Feeding opening

5 - Concave

8 - Output seeds opening

11- Belt
3 - Cover

6 - Expel opening

9 - pulley

12- Electric motor

\section{Fig. 1. The manufactured peanut Sheller}

\section{Shelling losses.}

The shelling losses were calculated as the following relation:

$$
S l, \%=\frac{M_{l o}}{M_{t}} \times 100
$$


Where:

$M_{l o}=$ mass of seeds losses, $\mathrm{kg}$,

$M_{\mathrm{t}} \quad=$ total mass of seeds, $\mathrm{kg}$.

\section{Shelling efficiency $(\eta)$ :}

Shelling efficiency of the mechanical sheller was estimated according to the following formula:

Shelling efficiency, $\%=\frac{M_{t}-M_{\text {uns }}}{M_{t}} \times 100$

Where:

$$
\begin{aligned}
& M_{t} \quad=\text { total mass of seeds, } \mathrm{kg}, \\
& M_{\text {uns }} \quad=\text { mass of unshelling seeds, } \mathrm{kg} .
\end{aligned}
$$

\section{Machine productivity (MP):}

Time of shelling was measured by means of a stopwatch ( $\mathrm{T}$, min) to determine the machine productivity in $\mathrm{kg} / \mathrm{h}$. The machine productivity was calculated as follow:

$$
M P=(M / T) \times 60
$$

\section{Cleaning ratio:}

Cleaning ratio after removing the impurities (on mass basis) was calculated as follows:

$$
C L_{r}, \%=\frac{M_{c l}}{M_{t}} \times 100
$$

Where:

$$
\begin{aligned}
& C L_{r}=\text { cleaning ratio, } \%, \\
& M_{c l}=\text { mass of clean sample, } \mathrm{kg}, \\
& M_{\mathrm{t}}=\text { total mass of seeds, } \mathrm{kg} .
\end{aligned}
$$

\section{RESULTS AND DISSECTION}

The results in Fig. 2 showed that, there is a positive relationship between the drum rotary speed and feeding rate on the damaged seeds percentage. The mechanical damage was observed to be increased with increase of drum rotary speed and feeding rate. Increasing drum rotary speed from 150 to 300 $\mathrm{rpm}(2.0$ to $4 \mathrm{~m} / \mathrm{s})$ tends to increase the average of damaged seeds 
percentage from 2.88 to $6.1 \%$ at feeding rates from 170 to $250 \mathrm{~kg} / \mathrm{h}$. This increase was due to higher impact levels and partially on friction force imparted to the crop during threshing at higher drum speeds. At the same time, the results indicated that, the seed damage increased with an increase in feeding rate. Increasing feeding rates from 170 to $250 \mathrm{~kg} / \mathrm{h}$ increased the average of damaged seeds percentage from 3.69 to $5.41 \%$ at drum rotary speeds ranged from 150 to $300 \mathrm{rpm}$.

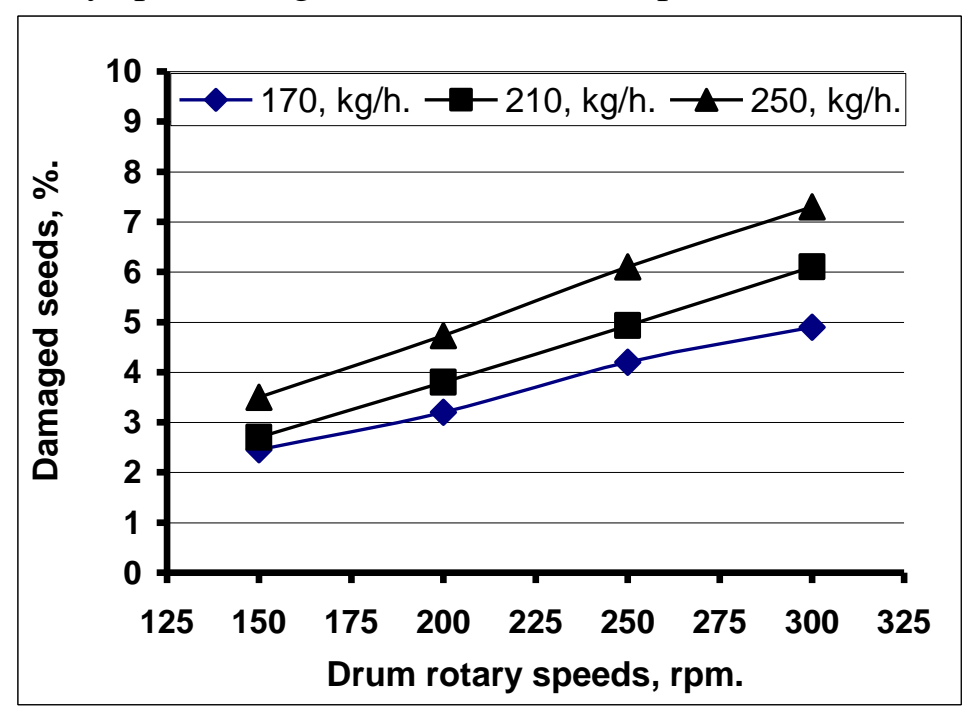

Fig. 2. show the effect of drum rotary speed and feeding rate on the damaged seeds percentage.

The results in Fig. 3 revealed that, there is a positive relationship between the drum rotary speed and feeding rate on the seeds losses percentage. Increasing drum rotary speeds from 150 to $300 \mathrm{rpm}$ tends to increase the average of seed losses percentage from 1.52 to $3.35 \%$ at feeding rates ranged from 170 to $250 \mathrm{~kg} / \mathrm{h}$. Also, increasing feeding rates from 170 to $250 \mathrm{~kg} / \mathrm{h}$ increased the average of seeds losses percentage from 2.11 to $2.74 \%$ at drum rotary speeds ranged from 150 to $300 \mathrm{rpm}$. The highest seed losses percentage of $3.7 \%$ was obtained at drum rotary speed of 300 $\mathrm{rpm}(4 \mathrm{~m} / \mathrm{s})$ and feeding rate of $250 \mathrm{~kg} / \mathrm{h}$. The least seed losses percentage of $1.32 \%$ was obtained at drum rotary speed of $150 \mathrm{rpm}(2.0 \mathrm{~m} / \mathrm{s})$ and feeding rate of $170 \mathrm{~kg} / \mathrm{h}$. 


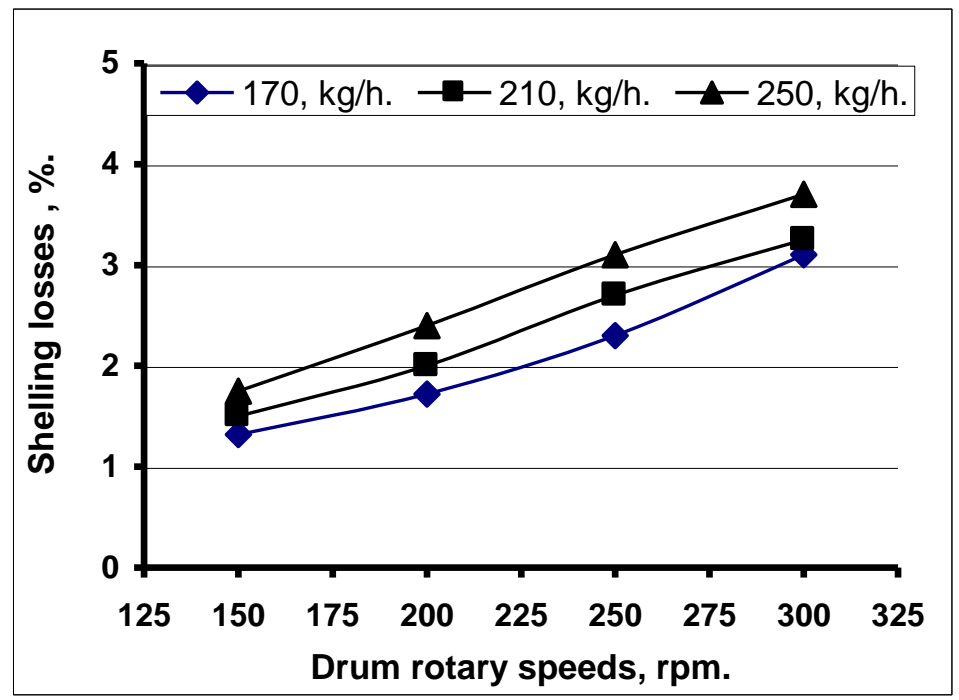

Fig. 3. Effect of drum rotary speed and feeding rate on the shelling losses.

The results in Fig. 4 indicated that, there is an inverse relationship between the drum rotary speed and feeding rate on the undamaged seeds percentage. Increasing drum rotary speeds from 170 to $300 \mathrm{rpm}$ led to decrease the average of undamaged seeds percentage from 97.12 to 93.9 at feeding rates ranged from 170 to $250 \mathrm{~kg} / \mathrm{h}$. At the same time, increasing feeding rates from 170 to $250 \mathrm{~kg} / \mathrm{h}$ decreased the average of undamaged seeds percentage from 96.31 to $94.59 \%$ at drum rotary speed ranged from 150 to $300 \mathrm{rpm}$. The highest undamaged seeds percentage of $97.55 \%$ was obtained at drum rotary speed of $150 \mathrm{rpm}$ and feeding rate of $170 \mathrm{~kg} / \mathrm{h}$.

The results in Fig. 5 showed that, there is a positive relationship between the drum rotary speed and feeding rate on the un-shelling pods percentage. Increasing drum rotary speed from 150 to $300 \mathrm{rpm}$ tends to increase the average of un-shelling pods percentage from 1.43 to $3.1 \%$ at feeding rates from 170 to $250 \mathrm{~kg} / \mathrm{h}$. Also, the results indicated that, the un-shelling pods increased with an increase in feeding rate. Increasing feeding rates from 170 to $250 \mathrm{~kg} / \mathrm{h}$ led to increase the average of un- 
shelling pods percentage from 1.91 to $2.55 \%$ at drum rotary speeds ranged from 150 to $300 \mathrm{rpm}$. It was also observed that peanut pods with one seed per pod and those with two small seeds in their pods were the ones that came out unshelled.

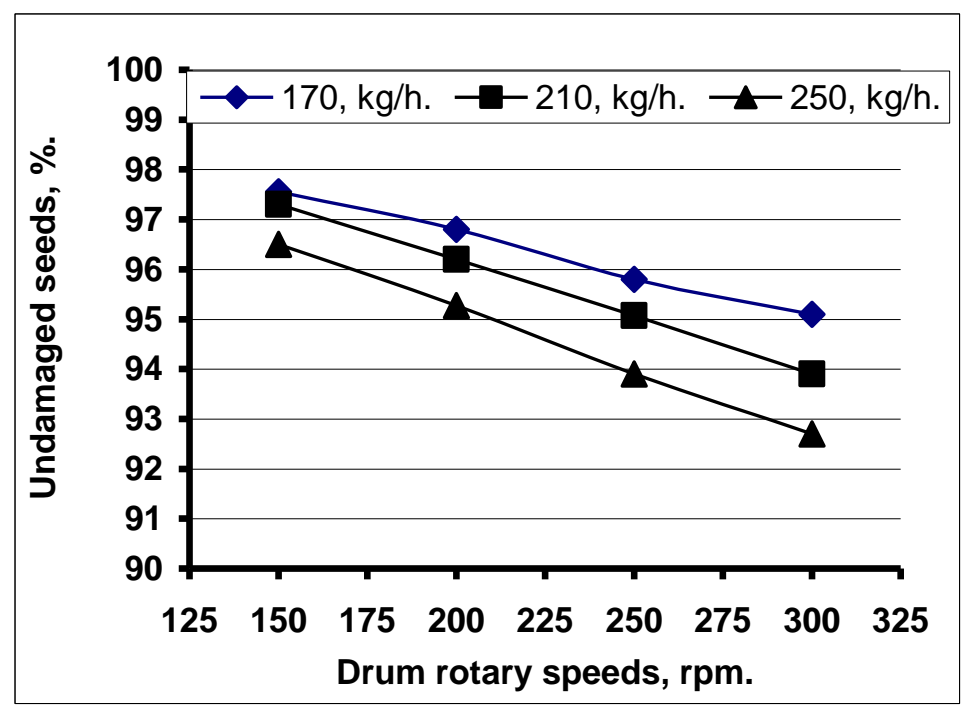

Fig. 4. Effect of drum rotary speed and feeding rate on the undamaged seeds percentage.

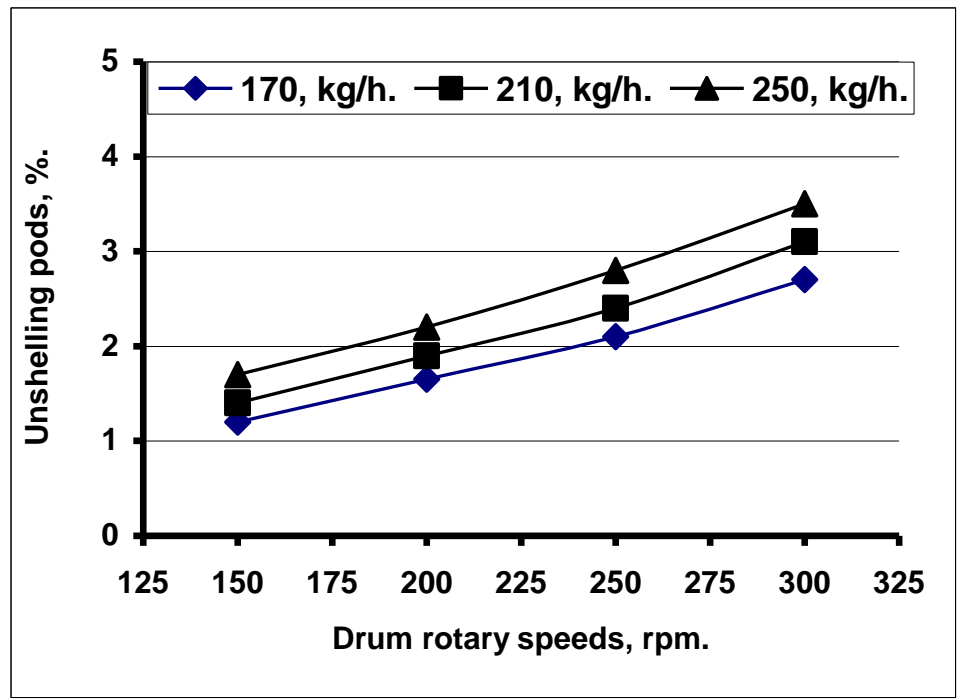

Fig. 5. Effect of drum rotary speed and feeding rate on the unshelling pods percentage. 
The results in Fig. 6 indicated that, there is an inverse relationship between the drum rotary speed and feeding rate on the shelling efficiency. Increasing drum rotary speeds from 170 to $300 \mathrm{rpm}$ led to decrease the average of shelling efficiency from 95.59 to $90.55 \%$ at feeding rates ranged from 170 to $250 \mathrm{~kg} / \mathrm{h}$. At the same time, increasing feeding rates from 170 to $250 \mathrm{~kg} / \mathrm{h}$ decreased the average of shelling efficiency from 94.2 to $91.86 \%$ at feeding rates ranged from 170 to $250 \mathrm{~kg} / \mathrm{h}$. The highest shelling efficiency of $96.23 \%$ was obtained at drum rotary speed of 150 $\mathrm{rpm}$ and feeding rate of $170 \mathrm{~kg} / \mathrm{h}$. But the lowest shelling efficiency of $89 \%$ was obtained at drum rotary speed of $300 \mathrm{rpm}$ and feeding rate of $250 \mathrm{~kg} / \mathrm{h}$.

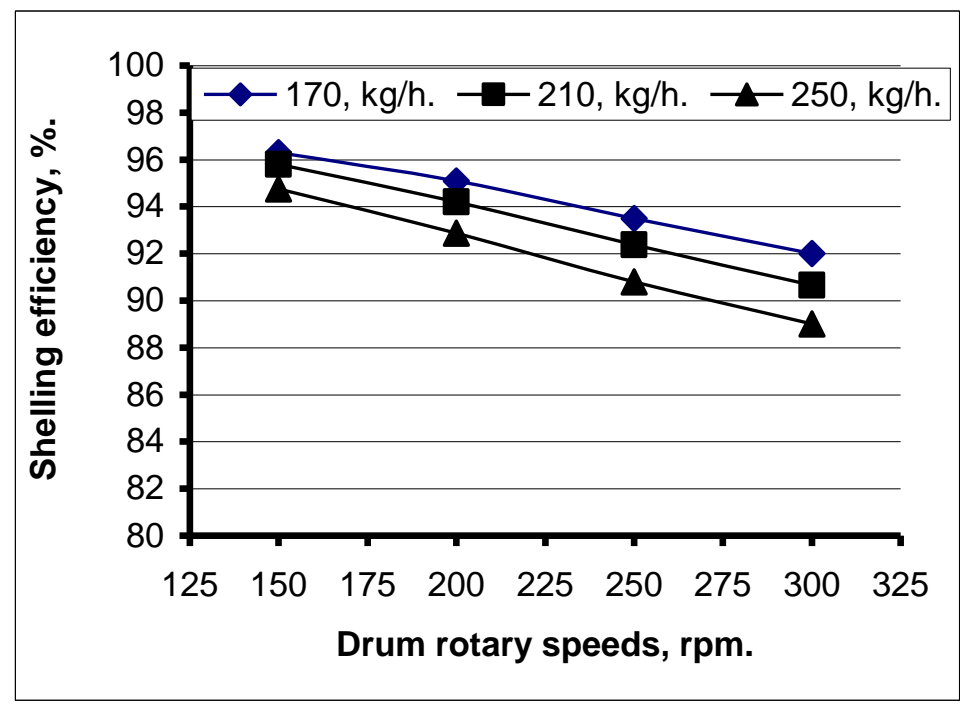

Fig. 6. Effect of drum rotary speed and feeding rate on the shelling efficiency.

The results in Fig. 7 revealed that, there is a positive relationship between the drum rotary speed and feeding rate on the machine productivity. Increasing drum rotary speeds from 150 to $300 \mathrm{rpm}$ led to increase the average of machine productivity from 140.51 to $210 \mathrm{~kg} / \mathrm{h}$ at feeding rates ranged from 170 to $250 \mathrm{~kg} / \mathrm{h}$. Also, increasing feeding rates from 170 to $250 \mathrm{~kg} / \mathrm{h}$ increased the average of machine productivity from 113.14 to 
$205.12 \mathrm{~kg} / \mathrm{h}$ at drum rotary speeds ranged from 150 to $300 \mathrm{rpm}$. The highest machine productivity of $250 \mathrm{~kg} / \mathrm{h}$ was obtained at drum rotary speed of $300 \mathrm{rpm}$ and feeding rate of $250 \mathrm{~kg} / \mathrm{h}$. The least machine productivity of $110.21 \mathrm{~kg} / \mathrm{h}$ was obtained at drum rotary speed of $150 \mathrm{rpm}$ and feeding rate of $170 \mathrm{~kg} / \mathrm{h}$.

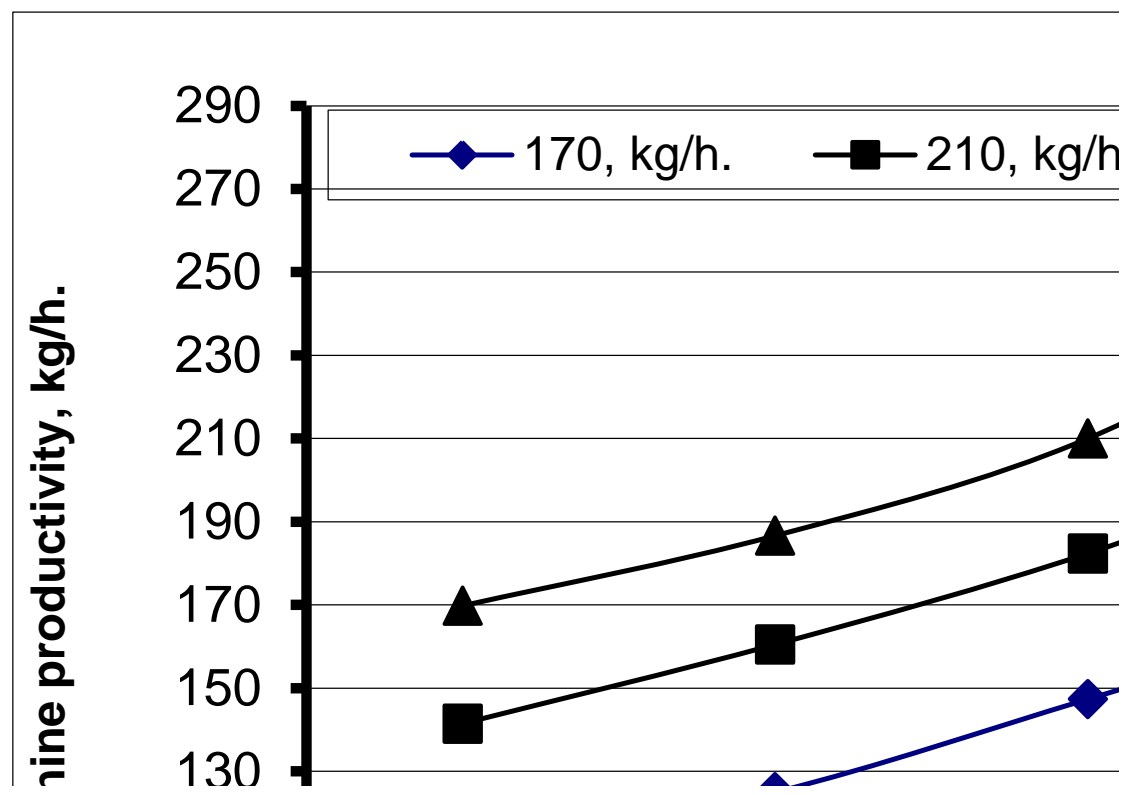

Fig. 7. Effect of drum rotary speed and feeding rate on the machine productivity.

The results in Fig. 8 indicated that, there is an inverse relationship between the drum rotary speed and cleaning ratio. Increasing drum rotary speeds from 150 to $300 \mathrm{rpm}$ led to decrease the average of cleaning ratio from 97.3 to $95.6 \%$ at air speeds ranged from 4.9 to $8.8 \mathrm{~m} / \mathrm{s}$. But, there is a positive relationship between the air speed and clean ratio. Increasing air speeds ranged from 4.9 to $8.8 \mathrm{~m} / \mathrm{s}$ increased the average of cleaning ratio from 95.75 to $97.3 \%$ at drum rotary speeds from 150 to $300 \mathrm{rpm}$. The highest cleaning ratio of $98 \%$ was obtained at drum rotary speed of $150 \mathrm{rpm}$ and air speed of $8.8 \mathrm{~m} / \mathrm{s}$. But the lowest cleaning ratio of $94.8 \%$ was obtained at drum rotary speed of $300 \mathrm{rpm}$ and air speed of $4.9 \mathrm{~m} / \mathrm{s}$. 


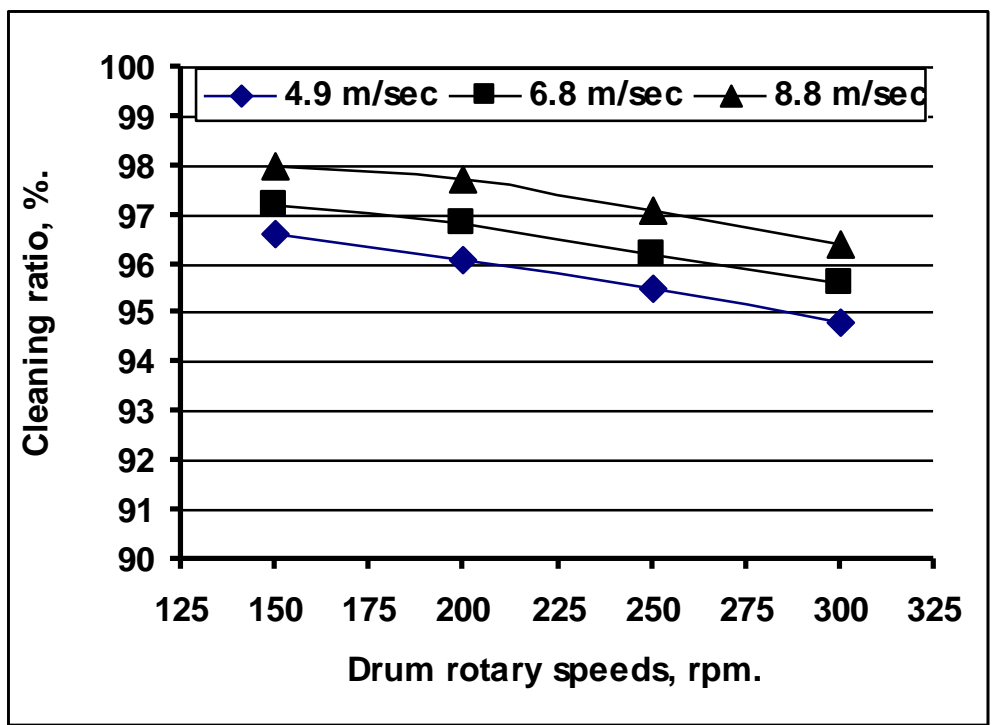

Fig. 8. Effect of drum rotary speed and air velocity on the cleaning ratio.

\section{CONCLUSION}

This work presents the manufacture of an electrically powered peanut shelling machine. The machine was fabricated using materials that were sourced locally. The obtained results reveal to the following:

1- Increasing drum rotary speed and feeding rate tends to increase each of damaged seeds, shelling losses, un-shelling pods and machine productivity.

2- Increasing drum rotary speed and feeding rate tends to decrease each of undamaged seeds shelling efficiency.

3- The lowest seed damaged and shelling losses of 2. $\leqslant 0$ and Ir \% and the highest undamaged seeds, shelling efficiency of 97.55 and $96.23 \%$ were obtained at drum speed of $150 \mathrm{rpm}(2.0 \mathrm{~m} / \mathrm{s})$ and feeding rate of $170 \mathrm{~kg} / \mathrm{h}$.

4- It was also observed that peanut pods with one seed per pod and those with two small seeds in their pods were the ones that came out unshelled or partially shelled.

5- The test result showed that, the machine can shell a total of 250 $\mathrm{kg} / \mathrm{h}$ of peanut pods. 
6- Increasing air speeds ranged from 4.9 to $8.8 \mathrm{~m} / \mathrm{s}$ increased the average of cleaning ratio from 95.75 to $97.3 \%$.

7- The highest cleaning ratio of $98 \%$ was obtained at drum rotary speed of $150 \mathrm{rpm}$ and air speed of $8.8 \mathrm{~m} / \mathrm{s}$. But the lowest cleaning ratio of $94.8 \%$ was obtained at drum rotary speed of $300 \mathrm{rpm}$ and air speed of $4.9 \mathrm{~m} / \mathrm{s}$.

\section{REFERANCES}

Abdel-Rahim Y.M. (1994). Conceptual design modeling of cone thresher. Misr J. of Ag. Eng. 11(1):239-247.

Abo El-Kheir, M.M and A.Z. Shoukr (1993). Modeling of the action of mechanical shelling of peanut for different materials of beater drum. Misr J. AG. Ehg., 10(1):123-135.

Awady M. N. and A.S. El-sayed (1994). Separation of peanut seeds by air stream. Misr J. Eng. 11(1):137-147.

CAPMAS, Central Agency for Public Mobilization and Statistics (2014). Annual statistics bulletin of crop areas and production plants. Arab Republic of Egypt. Ref. No. 71-22122- 2013. P:53. In Arabic.

Duraisamy, V.M. and R. Manian, (1990). Design, development and evaluation of castor bean sheller. Agric. Mech. In Asia, Africa and Latin America., 21(2):41-45.

El-Sayed, A.S. (1992). A simple prototype of conical sheller for peanut seeds. Misr j. Agric. Eng., 9(2):149-159.

Gore, K.L: Gupta. C.P and G. Singh (1990). Development of poweroperated groundnut Agric. Mech. In Asia, Africa and Latin America., 21(3):38-44.

Helmy, M. A. (1999). Evaluation of a reciprocating peanut sheller. 7 conference of Misr Society, Agr. Eng. 27-28 October:139-161. 
Hemeada, M.A. (1974). A study of some factors affecting the operation of shelling Egyptian peanuts. M.Sc. thesis. Fac. Of Agri. Alex. Univ. Alex.

Ibrahim, A.A: Sabbah M.A and M.A. Hemeada (1976). Effect of some operation factors on peanut shelling. Alex. J. Agric. Res. 24(2):211220. Alexandria Univ. Egypt.

Ikechukwu, C.U., Olawale, J.O., and B.I. Ibukun (2014). Design and fabrication of groundnut shelling and separating machine. International Journal of Engineering Science Invention ISSN (Online): 2319-6734, ISSN (Print): 2319-6726 www.ijesi.org 3 Issue (4\|) \| PP.60-66.

Kittichai, T. (1984). Development and test of a power-operated groundnut sheller. M. Eng. Thesis No. AE-84-11, Asian Institute of Technology, Bangkok.

Mady, M. A., (2000). Development and evaluation of a power operated peanut sheller. Misr, J. Ag. Eng., 17 (3): 697-711.

Ntare, B. R., Diallo, A.T. Ndjeunga, J. and F. Waliyar (2014). Groundnut Seed Production Manual. Patancheru 502 324, Andhra Pradesh, India: International Crops Research Institute for the SemiArid Tropics (ICRISAT).

Singh, G. and P. Thongsawatwong (1983). Evaluation and modification of two peanut shellers. Agric. Mech. In Asia, Africa and Latin America., 14(3): 33- 40.

Singh, G. (1993). Development of a unique groundnut decorticator. AMA., 24 (1): 55- 64.

Tayel, S.A. and M.F.A. Khairy, (1988). A study on some design criteria of sunflower shelling machine. Misr J. Agric. Eng., 5(3):307-316.

Zafar, A.W.: S.A. Kalwar, M.T. Anwar (1997). Design and development of FMI axial flow groundnut thresher. Agric. Mech. In Asia, Africa and Latin America. 28(1):31- 34. 


\section{الملخص ألعربي}

\section{تصنيع وتقييم نموذج بسيط لآلة تقشير الفول السوداني}

محمد عطية ماضي

أجريت هذه الدر اسة بهدف تصنيع وتقييم نموذج بسيط لآلة تقشير الفول السوداني وقد أجريت

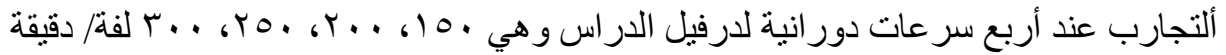

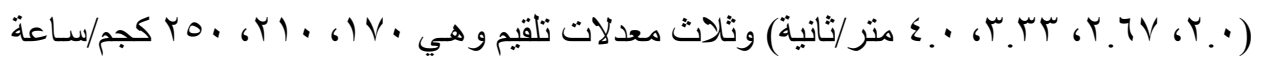

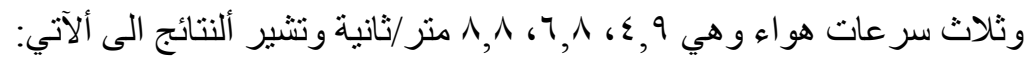

1 - زيادة كلا من ألسر عة ألدور انية للارفيل ومعدل التلقيم أدى إلى زيادة نسبة كلا من البذور التالفة و البذور المفقودة و القرون الغير مقشرة و الإنتاجية.

r- زيادة كلا من ألسر عة ألدور انية للارفيل ومعدل التلقيم أدى إلى نقص كلا من نسبة البذور السليمة (الغير تالفة) وكفاءة التقتير.

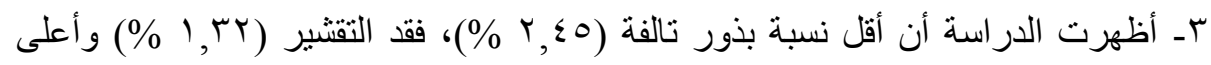

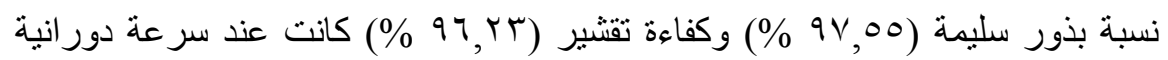

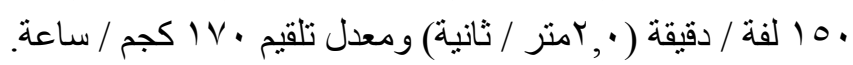

ع ـ أظهرت الدراسة أن آلة تقتشير الفول السوداني يمكنها تقتشير حتى . • ك كجم /ساعة.

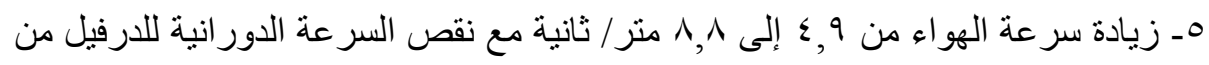

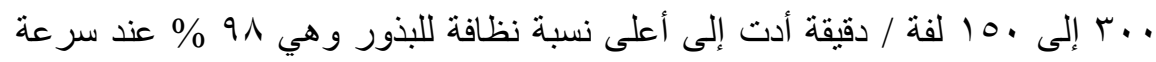

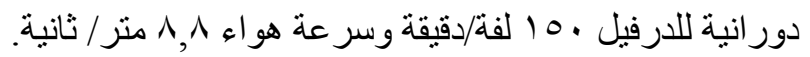

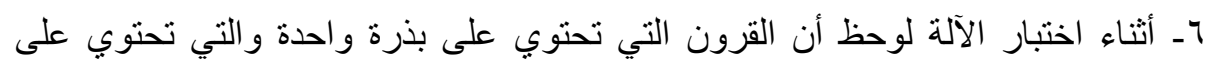

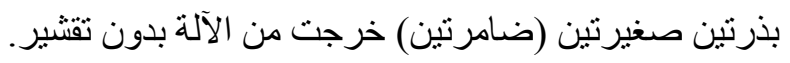

*أستاذ مساعد بقسم ألهندسة الزراعية ـ كلية الزراعة - جامعة قتاة السويس. 